\title{
Patient Advocacy Group
}

National Cancer Institute

\section{Source}

National Cancer Institute. Patient Advocacy Group. NCI Thesaurus. Code C54151.

An org anization that works to safeguard patients through effective mediation assuring access to care, maintenance of employment and preservation of their financial stability. 